MARTIN BRESTOVANSKÝ

Forum Pedagogiczne

Faculty of Education

2016/2 cz. 1

Trnava University

Received: 16.03 .2016

Accepted: 24.05.2016

Trnava (Slovakia)

DOI: $10.21697 /$ fp.2016.2.19

\title{
PROSOCIAL MORAL REASONING AND BEHAVIOURS: THE ROLE OF ETHICS EDUCATION ${ }^{1}$
}

\begin{abstract}
The relationship between students' evaluation of the school subject Ethics Education and students' type of prosocial moral reasoning and behaviours is described in the study. Prosocial moral reasoning, prosocial behaviour in the school questionnaire, and our own Ethics Education evaluation measure was used in the study. Research sample included students of $6^{\text {th }}$ grades of 26 primary schools from the western part of Slovakia: 579 participants $\left(49,7 \%\right.$ female, $\left.M_{\text {age }}=11,27 ; \mathrm{SD}=.71\right)$. There is evidence which supports the idea that the positive attitude to Ethics Education is linked to developmentally higher types of reasoning and higher prevalence of prosocial behaviours.
\end{abstract}

Keywords: prosocial moral reasoning, prosocial behaviour, Ethics education, prosocial education.

In the current survey of one of the most respected Slovak research agencies Focus (August, 2015 in "Naše novinky") respondents answered the question which subjects they lack in school. The requirement for the subject "developing morals, relationships and respect for elders" occurred in the first place (14\%). Given the more than 20-year history of Ethics Education in Slovakia, it is a striking result. It points to critically low recognition of the subject's contribution in society, as well as in school management, students and parents. This situation is in sharp contradiction with educational trends in the world (particularly in the transatlantic area), where character education is one of the primary objectives of school policy. Many of the specific projects were systematically described in a number of review studies (Berkowitz, Bier 2005; Kanacri 2011; CASEL 2013). In general, character education is based on social skills training. The project of Ethics Education in Slovakia as a school subject is strongly inspired by this approach, focused on the

1 The article is funded by VEGA nm. VEGA č. 1/0962/13 Teoretické preskúmanie a empirické overenie konceptu prosociálnosti ako výhodiskovej bázy aktuálnej koncepcie Etickej výc hovy v SR. 
practical development of pro-social tendencies. On the other hand, it differs from social skills trainings owing to the emphasis on moral reflection.

\section{Ethics Education Conception in Slovakia}

There is no doubt that communist totalitarianism led the Central European countries into deep social, economic and moral breakdown. The purposes of educational reforms after the Velvet Revolution (1989) included the task of remedying the totalitarian deformations in the educational system and to bring new educational concepts. The commission presided by Ladislav Lencz, established by the Slovak Ministry of Education in 1990, was entrusted to revitalize an effective character formation in schools. There was not enough time to create and evaluate brand new complex programmes through long-term experimental studies; it appeared that the best way would have been to adopt adequate foreign programmes, under, naturally, several conditions, i.e: they should be ideologically free; with evidence based project; complex (e.g. not only aggression prevention) programme; flexible enough to accommodate for special national circumstances so as to avoid big structural changes in educational system; humanistic; easy to organize in a short time for a huge number of schools (teachers' trainings etc.).

Within the Slovak educational system, Ethics Education became a part of the state school curriculum first in the low secondary education system (ISCED 2) in 1993, then in the higher secondary schools (ISCED 3) in 1995, and finally in the primary schools (ISCED 1) in 2004.

Ethics education is organized as a compulsory elective subject for pupils/students from the age of 6 to 15 years old $^{2}$ with one lesson per week time allocated, in every year of study during the ten years. During the lesson students in class are divided into two groups depending on their compulsory decision for one of two school subjects: Religious Education or Ethics Education. Approximately 25\% of pupils (or their parents) choose Ethics Education subject, the rest of them choose Religious Education. The teachers' training program Ethics Education is offered at seven faculties of education or philosophy in Slovakia.

The concept of Ethics Education is based on long-term research of prosociality (Roche 1985; 1992), which was in turn motivated by the wider research on the factors of positive character development (Mussen, Eisenberg 1979; Ryan, Lickona 1992; Battistich et al. 1995). Roche (1992) argues that the key to developing good character is just to promote prosocial behaviour. He identified ten basic factors which need to be developed in a child and five factors to evolve in a teacher/adult. Those ten factors formed the content of the prosocial education programme: (1) self-esteem, (2) communication skills, (3) positive evaluation of the others, (4) creativity and initiative;

2 In general, school system in Slovakia is divided into kindergartens (3-6 years old), primary schools (6-15), secondary schools/grammar schools (15-19), and higher education/universities (19+). 
(5) regulation of emotion and correct communication of emotions; (6) empathy; (7) assertiveness; (8) real and fictitious prosocial models; (9) individual prosocial behaviour skills (helping, sharing, donating etc.); and (10) complex and collective prosocial behaviour (cooperation, volunteering, prosocial policy, peace etc.).

\section{Similarities and differences between Slovak and Roche's prosocial education model}

Roche's programme was taken after certain adaptations including changes in content as well as in the procedural aspects. Strictly ethical topics have been added. After completing the basic set of ten topics, students are challenged to pass some applied ethics themes: (1) Ethics as a philosophy area; (2) Moral values in religions; (3) Moral values in economics; (4) My family; (5) Sexual health and responsible partnerships; and (6) Environmental issues. Lencz (1992) also enlarged Roche's model in methodological ways: the 3-steps experiential model was enlarged into a 4-steps model, including (1) raising cognitive and emotional sensitivity; (2) reflection of moral values; (3) practical training of social skills and reflection on praxis; (4) conceptualization and transfer to an individual and group's reality. The step of the reflection of moral values is the main difference between Roche's original and Slovak concept. The students' own moral considerations are of the highest priority, through them they are able to reorganize their own system of values and norms. So Ethics Education is not focused only on developing social skills, but it also emphasizes ethical aspects of social acts. Value education is the paramount interest of the subject. In this point of view social behaviour and responsibility is a type of an exam which checks personality qualities (Podmanický 2013).

\section{Research plan and methods}

Despite many years of implementation, only a few works reported on the effects of these educational programmes (see more Brestovanský 2014). Most of them had only local impact stressing the primarily practical issues of the ethics education in concrete situations (action research) or were focused on particular questions (ethics teacher's personality etc.). The research we describe below, is the first complex and representative attempt to find and analyse the general effects Ethics Education on prosocial behaviour and reasoning among 11-12 years old students.

We put forward a hypothesis that an increased score in prosocial behaviour and prosocial moral reasoning correlated with positive attitude to the subject of Ethics Education. Research plan included several stages: (1) during the first stage individual face-to-face (researcher-child) interviews were conducted, checking the children's understanding of the individual test items $(n=20)$. (2) After the basic understanding was ensured, a pilot study $(\mathrm{N}=254)$ and factor analysis were conducted to come to a final revision of the tests. (3) During these preparations teachers were 
contacted, selected and trained for participation in an experimental project. The criteria were as follows: (a) the location (Western Slovakia region), (b) education degree: graduate of the teaching programme Ethics Education, training program in this field, (c) at least two years of teaching praxis, (d) participation in methods trainings (two during the school year) to ensure a common understanding of the prepared methodical materials. (4) Pre-tests were conducted in October 2014. (5) From October 2014 until June 2015 controlled programme was carried out. (6) Post-tests were conducted in June 2015.

\section{Participants}

The main study assessed 579 participants (49,7 \% female, $\mathrm{M}_{\text {age }}=11,27$; SD =.71), students of $6^{\text {th }}$ grade enrolled in 26 lower secondary schools from the western part of Slovakia except Bratislava ${ }^{3} .82,1 \%$ participants live in intact families, complete with father and mother, and $83,9 \%$ live in a town with more the 10.000 inhabitants. The intervention group included 306 students (46,8\% female; 13 primary schools; $\mathrm{M}_{\text {age }}=11,30 ; \mathrm{SD}=.50$ ), control group included 271 students (54,2\% female; 13 primary schools; $\left.\mathrm{M}_{\text {age }}=11,22 ; \mathrm{SD}=.89\right) .355$ participants did post-tests $\left(49,30 \%\right.$ female; $\mathrm{M}_{\text {age }}$ $=11,93 ; \mathrm{SD}=0,43 ; 60,56 \% / \mathrm{n}=215$ in experimental group $/$ ).

\section{Measures}

A battery of questionnaires was administered, including (1) a revised version of the prosocial behaviour in school questionnaire (Roche, Sol 1998; translated by author of the paper), (2) assessment of prosocial moral reasoning - PROM (Carlo et al. 1992; translated by author of the paper), (3) a revised version of the Noo-dynamics Test (Popielski 1991; translated by Halama 1999), and (4) "prosocial dimensions" of Interpersonal Checklist (ICL) (LaForge et al. 1954; translated by Kožený, Ganický 1976). For concurrent validity the (prosocial) part of Goodman's Strengths and Difficulties Questionnaire was used. For Ethics Education school subject evaluation the short evaluation questionnaire was created.

\section{Prosocial Behaviour (PROS)}

We describe only two of the above mentioned instruments for the purposes of this study. Roche's questionnaire originally consists of 40 items representing ten various types of prosocial behaviour (physical help, physical service etc.; Roche, Sol 1998). E.g. the category "sharing" is represented by such items as "I allow my schoolmates to use my things and toys" or "I describe to my schoolmates various personal experiences". Because of huge number of items in all the tests, the number of

\footnotetext{
3 Based on Eurostat method of the EU regions distribution.
} 
items in Prosocial Behaviour Questionnaire was reduced by half. Pilot interviews played the key role in the reduction process. E.g. in category "attentive listening" the item "I keep silence while the other is speaking" was preferred over the item "I listen until the end" which seemed to be unclear for respondents. Three forms were distributed to participants: self-report, peer-report, and a form for teachers. In peer evaluation, random draw was conducted - every pupil was evaluated by just one schoolmate. Teacher evaluated all the students. Every item is scaled from 1 (I don't agree at all) to 4 (I completely agree). Reliability of PROS in different forms and stages was as follows (tab. 1).

Table 1. PROS: internal reliability

\begin{tabular}{lll|lll}
\hline Pre-test & N & Cronb. Alpha & Post-test & N & Cronb. Alpha \\
\hline Self-report & 526 & .818 & Self-report & 330 & .884 \\
Peer-report & 524 & .930 & Peer-report & 269 & .924 \\
Teacher's report & 572 & .931 & Teacher's report & 219 & .915 \\
\hline
\end{tabular}

Source: Author's own work.

The instrument content validity is based on classification of the different manifestations of pupils' pro-social behaviour in school (Roche, Sol 1998). The correlations with SDQ (Goodman 1997) were measured to gain concurrent validity, specifically with its five items that represent prosocial behaviour: PROS-self report and SDQself report $(\mathrm{r}=0.652, \mathrm{p}<0.001)$; PROS-peer report and SDQ-peer report $(\mathrm{r}=0.682$, $\mathrm{p}<0.001)$; PROS-teacher's report and SDQ-teacher's report $(\mathrm{r}=0.710, \mathrm{p}<0,001)$.

\section{Prosocial moral reasoning (PROM)}

Five from originally seven stories of PROM (Carlo et al. 1992) were selected for the study. Under each prosocial moral story dilemma, there are three behavioural choices listed as to what the character in the story should do, six reasons why the character should behave as specified (five categories of prosocial moral reasoning and one lie/nonsense item), and a ranking of how important each reason was in making their decision. The following is a sample story from the PROM: „Sandy was a student at school. One day Sandy was walking into her new class early and saw an older girl teasing and making fun of another girl's clothes. The girl was crying. There was no one else around and Sandy did not know the girls very well, but she had heard that the girl that was being teased was very poor and the older girl had a lot offriends. Sandy thought that maybe she should try to stop the older girl but she was afraid that the older girl and her friends might pick on her and tease her too."

Under each story, there are 3 behavioural choices listed as to what the character in the story should do (immediately under each PROM story dilemma), 6 reasons 
why the character should behave as specified, and a ranking of how important each reason was in making their decision. Each of the reasons (hedonistic, approval-oriented, stereotyped, needs-oriented, internalized) is scaled from 1 (not at all) to 5 (greatly). The category score is calculated as a sum of a category items divided by the sum of all of the category items scores. The following are the examples of the individual categories: "It depends whether Sandy can find other friends to do things with at school" (hedonistic); "It depends whether Sandy's classmates would approve of what she does" (approval-oriented); "It depends whether Sandy thinks the older girl is being really mean or not" (stereotyped); "It depends whether the other girl is crying a lot" (needs-oriented); "It depends whether Sandy thinks that she is doing what she believes she should do" (internalized).

The internal reliability of the measure involving 25 items ( 5 stories $\mathrm{x} 5$ types of reasoning) of the entire sample had the following characteristics (tab. 2). The results are divided by the measurement stage (pre-test / post-test). The prevalence and degree of lie/non-sense scores were assessed by using a specific lie/non-sense item in each story. The share of those who have reached a critical level lie score was 18.5\% (pre-test), $25.1 \%$ (post-test) respectively.

Items representing hedonistic type of moral reasoning are most problematic in terms of reliability, they are still on the edge of acceptability. For comparison, the comparative study, conducted by the author on Brazilian and American adolescents (Carlo et al. 1996), the level of reliability was very similar for different types of reasoning: hedonistic (.6o); approval-oriented (.85); needs-oriented (.66); stereotyped (.71); and internalized (.64).

Table 2. PROM: Internal reliability

\begin{tabular}{lll}
\hline Stage and type of reasoning & Cronb. Alpha \\
\hline Pre-test & hedonistic & .535 \\
& approval-oriented & .698 \\
& stereotyped & .758 \\
& needs-oriented & .744 \\
& internalized & .843 \\
\hline Post-test & hedonistic & .610 \\
& approval-oriented & .786 \\
& stereotyped & .736 \\
& needs-oriented & .733 \\
& internalized & .804 \\
\hline
\end{tabular}

Source: Author's own work. 


\section{Ethics education evaluation (EEE)}

For evaluation of the school subject Ethics Education, considering the high number of items in all the instruments, only a brief 7 -item questionnaire was created for the purpose of simple feedback to those who had completed a programme during the school year. It was distributed only to students (self-form), covering basic areas of their experiences: cognitive ("I consider Ethics Education lessons during the past year as very useful, I've learnt a lot"), affective ("EE lessons encouraged me, I was in a good mood after them"), social ("EE lessons strengthened our class group"), axiological ("EE lessons helped me to become better"). Three items were worded negatively (“... useless, didn't teach me anything”; “... boring”; etc.) A scale from 1 to 4 (strongly disagree - strongly agree) was used. Internal reliability of the positive items was Cronb. Alpha $=.702$, internal reliability of the negative items was Cronb. Alpha $=.729(\mathrm{~N}=178)$.

\section{Results}

\section{Prosocial Behaviour}

Total score of prosocial behaviour could, as mentioned above, range from 18 to 72 points (18 items with the scale 1-4) (tab. 3). Within two measurements (pre-test/ post-test) mainly self-report significantly varied towards the lower score. Selfevaluation of pro-social behaviour, irrespective of gender, differs significantly from the peer's and teacher's assessment. The highest difference is in boys compared with an assessment of their peers. Self-assessment in post-test decreased in girls from the experimental group, while teachers have seen them more prosocial in the post-test. The average ratio for self-report score to peer-report score equals 1.18 in the pre-test and 1.17 in the post-test. Pupils overestimate themselves by about $17-18 \%$ average in comparison to the evaluation made by their classmates.

Regarding other demographic parameters, a massive difference in the assessment of students by teachers can be seen in smaller primary schools, located in villages with a population of under ten thousand. Teachers in the villages assessed their pupils as much more prosocial compared with teachers in towns (pre-test: 51.88 / 58.64, p <0.001; post-test: 53.62 / 57.67, $\mathrm{p}<0.001$ ). The difference occurs depending on the composition of the family. Children from intact families reported themselves as more prosocial $(54.94 / 52.06, \mathrm{p}<0.05)$ and this is how they tend to see their peers from intact families compared with those who live at home only with mother (50.66 / 47.28, p<0.05). 
Table 3. Differences in ratings of prosocial behaviour in different forms and stages

\begin{tabular}{|c|c|c|c|c|c|}
\hline \multicolumn{2}{|l|}{ Gender } & Rating form & M & $\mathrm{N}$ & SD \\
\hline \multirow{12}{*}{ Male } & \multirow{6}{*}{ 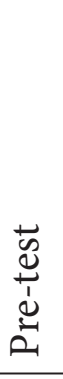 } & Self-report & $53,63^{x * *}$ & 215 & 7,92 \\
\hline & & Peer-report & $46,00^{* * *}$ & 215 & 11,87 \\
\hline & & Self-report & $53,86^{\star * *}$ & 235 & 7,85 \\
\hline & & Teacher's report & $50,42^{* * *}$ & 235 & 8,64 \\
\hline & & Peer-report & $45,64^{* * *}$ & 240 & 11,99 \\
\hline & & Teacher's report & $50,13^{* * *}$ & 240 & 9,20 \\
\hline & \multirow{6}{*}{$\begin{array}{l}\vec{y} \\
\frac{\tilde{y}}{1} \\
\frac{1}{0} \\
0 \\
0\end{array}$} & Self-report & $52,22^{* * *}$ & 151 & 9,38 \\
\hline & & Peer-report & $47,73^{\star * *}$ & 151 & 13,09 \\
\hline & & Self-report & 51,54 & 95 & 9,57 \\
\hline & & Teacher's report & 51,52 & 95 & 7,75 \\
\hline & & Peer-report & 48,64 & 95 & 13,74 \\
\hline & & Teacher's report & 51,37 & 95 & 7,63 \\
\hline \multirow{12}{*}{ Female } & \multirow{6}{*}{ 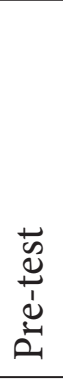 } & Self-report & $58,30^{* * *}$ & 219 & 6,65 \\
\hline & & Peer-report & $54,57^{* * *}$ & 219 & 10,19 \\
\hline & & Self-report & $58,56^{* * *}$ & 245 & 6,70 \\
\hline & & Teacher's report & $55,89^{\star * *}$ & 245 & 7,82 \\
\hline & & Peer-report & $54,33^{*}$ & 242 & 10,27 \\
\hline & & Teacher's report & $55,84^{*}$ & 242 & 7,87 \\
\hline & \multirow{6}{*}{$\begin{array}{l}\frac{\omega}{0} \\
\stackrel{\Delta}{1} \\
\frac{1}{0} \\
0 \\
0\end{array}$} & Self-report & $56,94^{* * *}$ & 140 & 7,70 \\
\hline & & Peer-report & $52,55^{* * *}$ & 140 & 12,09 \\
\hline & & Self-report & 57,32 & 99 & 8,15 \\
\hline & & Teacher's report & 57,11 & 99 & 7,59 \\
\hline & & Peer-report & $52,32^{* * *}$ & 89 & 12,40 \\
\hline & & Teacher's report & $57,49^{\star * *}$ & 89 & 6,92 \\
\hline
\end{tabular}

${ }^{* * *} \mathrm{p}<0.001 ;{ }^{* *} \mathrm{p}<0.01 ;{ }^{\star} \mathrm{p}<0.05$, Paired Samples T-test Source: Author's own work.

The positive impact of prosocial education program (Ethics Education) was put forward as a hypothesis. However, the programme significantly lowered self-evaluation in pro-social behaviour among girls (tab. 4) and they were evaluated even lower by their peers. On the other hand, the evaluation by the teachers grew sharply. Nevertheless, teachers in control group saw the girls significantly more critically in the post-tests. Interestingly, peer-ratings for boys improved significantly, both in the control group, and in the experimental one (close to significance; $p=0.133$ ). 
Table 4. Changes in prosocial behaviour ratings based on experimental intervention

\begin{tabular}{|c|c|c|c|c|c|c|}
\hline Group & Gender & Form & Stage & M & $\mathrm{n}$ & SD \\
\hline \multirow{12}{*}{ 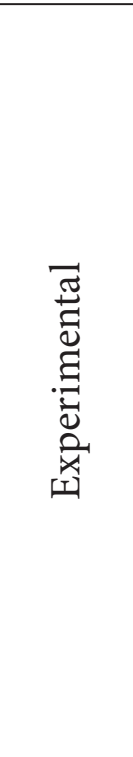 } & \multirow{6}{*}{ Male } & \multirow{2}{*}{ Self-report } & Pre-test & 54,17 & 90 & 7,93 \\
\hline & & & Post-test & 52,77 & 90 & 8,59 \\
\hline & & \multirow{2}{*}{ Peer-report } & Pre-test & 46,28 & 89 & 11,18 \\
\hline & & & Post-test & 48,65 & 89 & 12,06 \\
\hline & & \multirow{2}{*}{ Teacher's report } & Pre-test & 49,33 & 64 & 9,03 \\
\hline & & & Post-test & $51,52^{*}$ & 64 & 7,89 \\
\hline & \multirow{6}{*}{ Female } & \multirow{2}{*}{ Self-report } & Pre-test & 58,75 & 91 & 6,68 \\
\hline & & & Post-test & $55,93^{* * *}$ & 91 & 7,64 \\
\hline & & \multirow{2}{*}{ Peer-report } & Pre-test & 55,19 & 78 & 9,48 \\
\hline & & & Post-test & $52,56^{*}$ & 78 & 10,87 \\
\hline & & \multirow{2}{*}{ Teacher's report } & Pre-test & 55,55 & 65 & 7,58 \\
\hline & & & Post-test & $57,66^{* *}$ & 65 & 7,78 \\
\hline \multirow{12}{*}{$\begin{array}{l}\overline{0} \\
\stackrel{\Xi}{\Xi} \\
\dot{0}\end{array}$} & \multirow{6}{*}{ Male } & \multirow{2}{*}{ Self-report } & Pre-test & 53,78 & 55 & 8,36 \\
\hline & & & Post-test & 51,27 & 55 & 10,34 \\
\hline & & \multirow{2}{*}{ Peer-report } & Pre-test & 43,12 & 52 & 14,63 \\
\hline & & & Post-test & $47,60^{* *}$ & 52 & 15,33 \\
\hline & & \multirow{2}{*}{ Teacher's report } & Pre-test & 51,43 & 44 & 8,34 \\
\hline & & & Post-test & 50,80 & 44 & 7,52 \\
\hline & \multirow{6}{*}{ Female } & \multirow{2}{*}{ Self-report } & Pre-test & 60,05 & 56 & 7,44 \\
\hline & & & Post-test & 58,38 & 56 & 7,71 \\
\hline & & \multirow{2}{*}{ Peer-report } & Pre-test & 55,22 & 50 & 12,48 \\
\hline & & & Post-test & 53,60 & 50 & 12,74 \\
\hline & & Teacher's report & Pre-test & 59,66 & 44 & 6,96 \\
\hline & & & Post-test & $55,75^{* * *}$ & 44 & 7,47 \\
\hline
\end{tabular}

${ }^{*} \mathrm{p}<0.1 ;{ }^{*} \mathrm{p}<0.05 ; \mathrm{p}<0.001$; Paired samples T-test

Source: Author's own work.

\section{Prosocial moral reasoning}

There were significant changes in prosocial moral reasoning during the year, taking into account the whole group of respondents. According to developmental assumptions, hedonistic reasoning statistically significantly decreased in favour of internalised, approval-oriented, and stereotyped reasoning. But if a closer look is 
taken at the distribution of changes, we find that improvement is only fortified by changes in the control group (tab. 5). E.g. hedonistic reasoning rate in the control group fell from.212 down to.179. However, it should be noted high standard deviation in the pre-test and a very high primary (pre-test) value (.212).

Table 5. Differences in prosocial moral reasoning based on experimental intervention

\begin{tabular}{|c|c|c|c|c|c|}
\hline Type of reasoning & Group & Stage & Mean & $\mathrm{N}$ & St. Deviation \\
\hline \multirow{4}{*}{ Hedonistic } & \multirow{2}{*}{ Experimental } & Pre-test & .185 & \multirow{2}{*}{154} & ,0340 \\
\hline & & Post-test & .185 & &, 0303 \\
\hline & \multirow{2}{*}{ Control } & Pre-test & .212 & \multirow{2}{*}{94} &, 0609 \\
\hline & & Post-test & $.179^{* * *}$ & & ,0341 \\
\hline \multirow{4}{*}{ Approval-oriented } & \multirow{2}{*}{ Experimental } & Pre-test & .170 & \multirow{2}{*}{154} &, 0358 \\
\hline & & Post-test & .167 & &, 0387 \\
\hline & \multirow{2}{*}{ Control } & Pre-test & .196 & \multirow[b]{2}{*}{94} & ,0459 \\
\hline & & Post-test & $.176^{* * *}$ & & ,0368 \\
\hline \multirow{4}{*}{ Stereotyped } & \multirow{2}{*}{ Experimental } & Pre-test & .218 & \multirow{2}{*}{154} & ,0287 \\
\hline & & Post-test & .217 & & ,0291 \\
\hline & \multirow{2}{*}{ Control } & Pre-test & .193 & \multirow[b]{2}{*}{94} & ,0390 \\
\hline & & Post-test & $.214^{* * *}$ & &, 0303 \\
\hline \multirow{4}{*}{ Needs-oriented } & \multirow{2}{*}{ Experimental } & Pre-test & .196 & \multirow{2}{*}{154} & ,0317 \\
\hline & & Post-test & .196 & & ,0337 \\
\hline & \multirow{2}{*}{ Control } & Pre-test & .200 & \multirow{2}{*}{94} & ,0349 \\
\hline & & Post-test & .206 & & ,0295 \\
\hline \multirow{4}{*}{ Internalized } & \multirow{2}{*}{ Experimental } & Pre-test & .232 & \multirow{2}{*}{154} &, 0341 \\
\hline & & Post-test & .235 & & ,0330 \\
\hline & \multirow{2}{*}{ Control } & Pre-test & .200 & \multirow{2}{*}{94} &, 0456 \\
\hline & & Post-test & $.225^{* * *}$ & &, 0342 \\
\hline
\end{tabular}

${ }^{* * *} \mathrm{p}<0.001$, Paired Samples T-test

Source: Author's own work.

\section{Student's attitudes to Ethics Education in relation to prosocial behaviour and moral reasoning}

Positive relationship between prosocial behaviour and attitudes to EE subject was assumed. As mentioned above, a brief 7 -item questionnaire was used to measure 
student's evaluation, it could range from 7-28 (mean $=20.86, \mathrm{SD}=3.87$ ). Surprisingly there are no differences in the assessment of the subject in terms of gender. As shown in the following table (tab. 6), those who belonged to the lowest quartile in the assessment of EE were perceived significantly less prosocial than those who rated the EE best. The relationship also applies to the assessment by peers. We also see a similar tendency among teachers, and although the difference is not significant, low standard deviation indicates the clear distinction of the two groups of students.

Table 6. Evaluation of prosocial behaviour regarding the relationship to Ethics Education

\begin{tabular}{|l|l|l|l|l|}
\hline Form of PROS & EE assessment & N & Mean & St. Deviation \\
\hline \multirow{2}{*}{ Self-report } & Lowest 25\% & 44 & 51,23 & 8,62 \\
\cline { 2 - 5 } & Highest 25\% & 48 & $\mathbf{5 6 , 0 6} \mathbf{6}^{\text {** }}$ & 8,99 \\
\hline \multirow{2}{*}{ Peer-report } & Lowest 25\% & 36 & 45,61 & 12,35 \\
\cline { 2 - 5 } & Highest 25\% & 41 & $\mathbf{5 1 , 4 6 ^ { * }}$ & 10,60 \\
\hline \multirow{2}{*}{ Teacher's report } & Lowest 25\% & $\mathbf{2 9}$ & $\mathbf{5 1 , 7 9}$ & 10,16 \\
\cline { 2 - 5 } & Highest 25\% & $\mathbf{2 7}$ & $\mathbf{5 5 , 1 1}$ & $\mathbf{6 , 6 8}$ \\
\hline
\end{tabular}

${ }^{* *} \mathrm{p}<0.01 ;{ }^{*} \mathrm{p}<0.05$; independent samples T-test

Source: Author's own work.

\section{Discussion}

The trends reported in pilot study (Brestovanský et al. 2015) were confirmed. Selfevaluation of pro-social behaviour, irrespective of gender, differs significantly from the peers' and teachers' assessment. The findings are consistent with other studies (Warden et al. 2003; Fetchenhauer, Dunning 2006; 2013), according to them, a person subjectively sees himself/herself significantly different what is seen by others. Thus, the initial differences in evaluations have been deleted after the experiment. It is worth noting the high standard deviation in the evaluation by peers, which may mean radically unbalanced positive / negative views.

If we take a closer look into the experimental group, two different groups could be recognized more precisely based on attitude to Ethics Education. The lowest quartile of students evaluating the subject is characterized with high score in hedonistic type of reasoning. Also the approval-oriented reasoning grew during the year in this group. In contrast, the highest quartile has a much lower score in hedonistic type, much higher in internalized type of reasoning, and also the approval-oriented reasoning in this group decreased during the experimental intervention (tab. 7). 
Tab. 7 Type of reasoning and EE evaluation

\begin{tabular}{|c|c|c|c|c|c|}
\hline $\begin{array}{l}\text { EE } \\
\text { evaluation }\end{array}$ & Type of reasoning & Stage & Mean & $\mathrm{N}$ & $\begin{array}{l}\text { Std. } \\
\text { Deviation }\end{array}$ \\
\hline \multirow{12}{*}{ 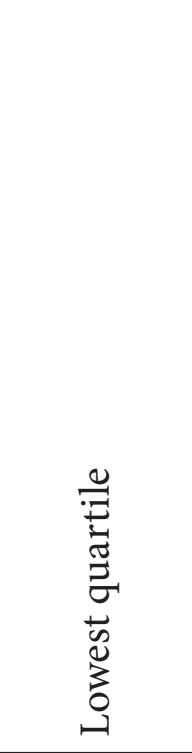 } & \multirow{2}{*}{ Hedonistic } & Pre-test & .196 & \multirow{2}{*}{39} & .0293 \\
\hline & & Post-test & .200 & & .0233 \\
\hline & \multirow{2}{*}{ Approval-Oriented } & Pre-test &, 167 & \multirow{2}{*}{39} & .0390 \\
\hline & & Post-test &, $179^{*}$ & & .0317 \\
\hline & \multirow{2}{*}{ Stereotyped } & Pre-test &, 211 & \multirow{2}{*}{39} & .0327 \\
\hline & & Post-test & ,207 & & .0224 \\
\hline & \multirow{2}{*}{ Needs-Oriented } & Pre-test & ,201 & \multirow{2}{*}{39} & .0310 \\
\hline & & Post-test & ,195 & & .0303 \\
\hline & \multirow{2}{*}{ Internalized } & Pre-test & ,226 & \multirow{2}{*}{39} & .0460 \\
\hline & & Post-test &, 219 & & .0267 \\
\hline & \multirow{2}{*}{ Composit } & Pre-test & 1,860 & \multirow{2}{*}{34} & .0906 \\
\hline & & Post-test & 1,855 & & .0628 \\
\hline \multirow{12}{*}{ 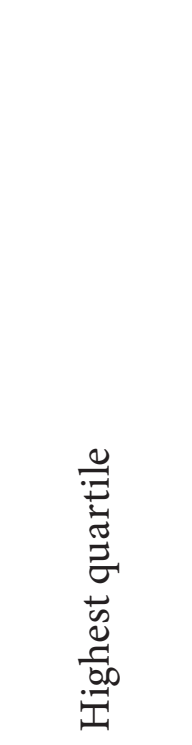 } & \multirow{2}{*}{ Hedonistic } & Pre-test & ,179 & \multirow{2}{*}{49} & .0410 \\
\hline & & Post-test & ,177 & & .0306 \\
\hline & \multirow{2}{*}{ Approval-Oriented } & Pre-test & ,170 & \multirow{2}{*}{49} & .0406 \\
\hline & & Post-test &, $155^{* * *}$ & & .0408 \\
\hline & \multirow{2}{*}{ Stereotyped } & Pre-test &, 223 & \multirow{2}{*}{49} & .0289 \\
\hline & & Post-test &, 222 & & .0282 \\
\hline & \multirow{2}{*}{ Needs-Oriented } & Pre-test & , 196 & \multirow{2}{*}{49} & .0293 \\
\hline & & Post-test & ,201 & & .0329 \\
\hline & \multirow{2}{*}{ Internalized } & Pre-test &, 232 & \multirow{2}{*}{49} & .0287 \\
\hline & & Post-test &, $244^{\star *}$ & & .0343 \\
\hline & \multirow{2}{*}{ Composit } & Pre-test & 1,887 & \multirow{2}{*}{62} & .0741 \\
\hline & & Post-test & $1,914^{* * *}$ & & .0786 \\
\hline
\end{tabular}

${ }^{* *} \mathrm{p}<0.01 ;{ }^{* *} \mathrm{p}<0.001$

Source: Author's own work.

It seems that EE lessons during one school year had no effect, it is even possible to talk about the negative barrier effects, assuming that the students in the control group optimize their prosocial moral reasoning in the context of non-intentional development process. The initial score of the students in the experimental group was significantly higher than of the students in the control group. Groups differed significantly in favour of the experimental one (e.g. hedonistic reasoning:.185/.212, 
$\mathrm{p}<0.001)$. Students in experimental group probably did not have enough potential for further change.

The control group in the year in which the experiment was conducted, actually only caught up with the experimental group in the development of prosocial moral reasoning. Following the correlation of the pre-test and post-test observations, the experimental group expressed high stability $(\mathrm{r}=.467, \mathrm{p}<0.001)$ compared to the control group $(\mathrm{r}=-.164, \mathrm{p}<0.1)$.

Respondents who belonged to the experimental group and who at the same time highly positively rated Ethics Education, were characterized by the highest score in internalized prosocial moral reasoning (.02439) and were much more prosocial from all the sample $(\mathrm{N}=579)$.

Finally, we describe the general model of correlations (fig. 1) in which all measured variables are included. As we can see, positive evaluation of Ethics education correlates with positive attitudes to the others as well as with students own prosocial behaviour as seen by themselves, peers, and teachers.

Figure 1. Correlations between EE evaluation and prosocial behaviour and moral reasoning

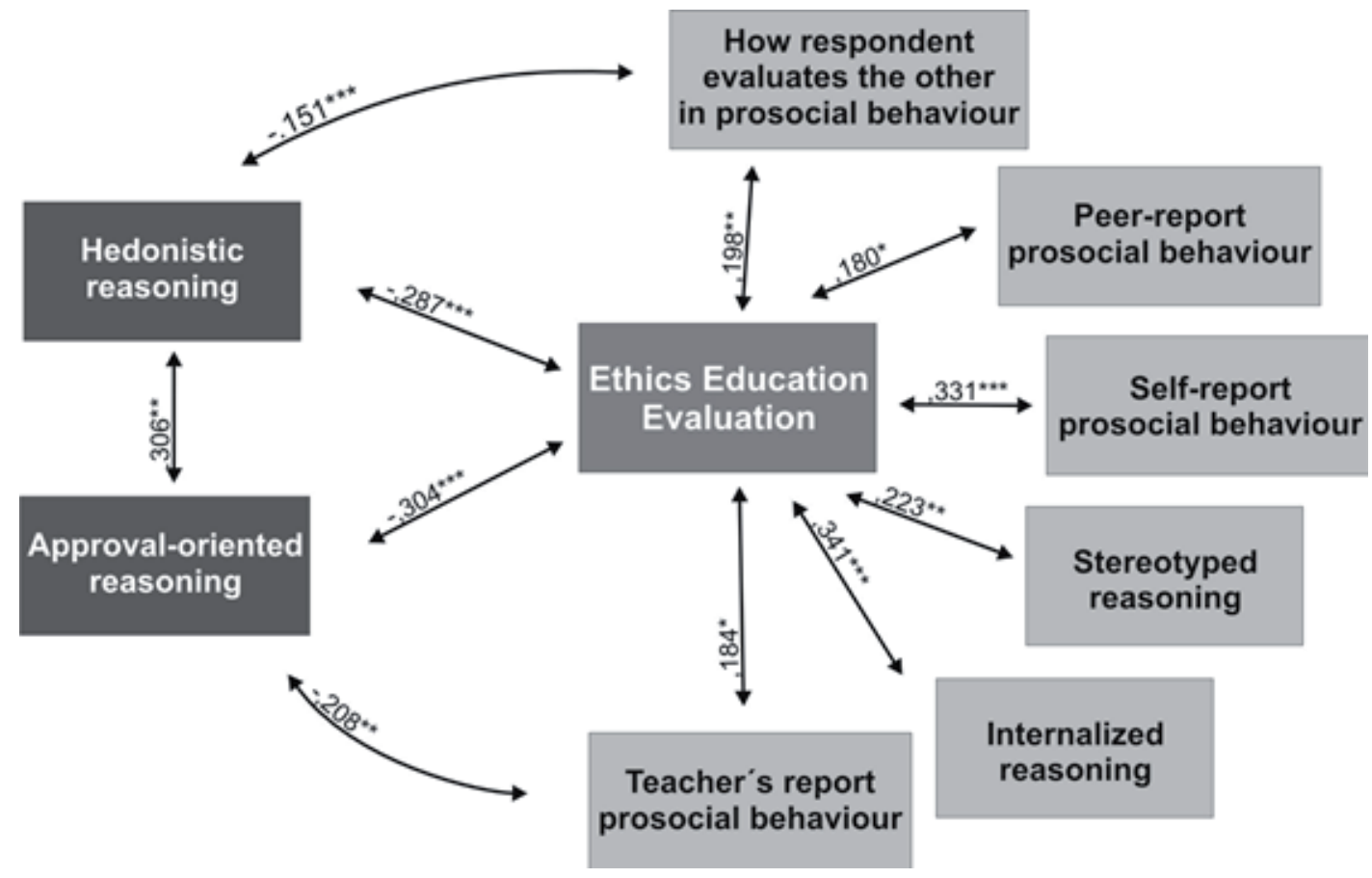

${ }^{*} \mathrm{p}<0.05,{ }^{* *} \mathrm{p}<0.01,{ }^{* *} \mathrm{p}<0.001$

Source: Author's own work. 


\section{Conclusion}

It seems that the school subject of Ethics Education has no significant effect on prosocial behaviour in itself. In closer look, the Ethics Education impact grows with positive student's attitudes to it. We think this is a consequence of the merger of several phenomena. Firstly, the problem of disparities between school culture, which doesn't encourage the formation of prosocial character. Ethic Education "taught" in such conditions may have the opposite effect. It is therefore necessary to examine the character education in schools not only in the context of one subject, but taking into account the whole school culture.

\section{References}

Aké predmety nám v školách chýbajú? „Naše novinky“, vol. 3, 17/2015, p. 14.

Babinčák P. (2011). Stabilita morálnych úsudkov v čase. Test-retest reliabilita vybraných nástrojov na meranie morálneho usudzovania. In: "Psychológia morálky". Available at: http://www.ff.unipo.sk/psymoral/download/stabilita_ moralnych_usudkov_v_case.pdf (Retrieved 22.05.2015).

Battistich V., Solomon D., Kim D., Watson M., Schaps E. (1995). Schools as communities, poverty levels of student populations, and students' attitudes, motives, and performance: A multilevel analysis. "American Educational Research Journal", vol 32, pp. 627-658.

Berkowitz M.W., Bier M.C. (2005). What Works In Character Education: A research-driven guide for educators. Missouri: CEP.

Brestovanský M. (2014). Metodologické otázky výskumu prosociálnosti. In: I. Podmanický, A. Rajský (eds.). Prosociálnost’ a etická výchova. Skúsenosti a perspektívy. Trnava: Typi Universitatis Tyrnaviensis.

Brestovanský M., Sádovská A., Podmanický I., Kusý P. (2015). Charakteristiky hodnotenia a sebahodnotenia prosociálneho správania u žiakov piatych a šiestych ročníkov vybraných základných škôl. "Studia Paedagogica”, vol. 20 (1), pp. 67-83.

Carlo G., Eisenberg N., Knight G.P. (1992). An Objective Measure of adolescents' Prosocial Moral Reasoning. "Journal of Research on Adolescence", vol. 2 (4), pp. 331-349.

CASEL (2012). Effective Social and Emotional Learning Programs. Available at: http://www.casel.org/guide/

Comer J.P. (1968). Comer School Development Program. Available at: http://medicine. yale.edu/childstudy/comer/

Eisenberg N. (1986). Altruistic emotion, cognition and behavior. Hillsdale, NJ: Erlbaum.

Fetchenhauer D., Dunning D. (2006). Perceptions of Prosociality and Solidarity in Self and Others. In: D. Fetchenhauer et al. (eds.). Solidarity and Prosocial 
Behavior. An Integration of Sociological and Psychological Perspectives. New York: Springer, pp. 61-74.

Gilligan C. (2001). Jiným hlasem. Praha: Portál.

Goodman R. (1997). The Strengths and Difficulties Questionnaire: A Research Note. "Journal of Child Psychology and Psychiatry", vol. 5 (38), pp. 581-586.

Hoffman M.L. (2000). Empathy and moral development. Implications for caring and justice. New York: Cambridge University Press.

Kanacri B.P.L. (2011). Development and Promotion of Prosocial Behavior from Adolescence to Young Adulthood: Antecedents and Civic Outcomes. Dissertation thesis. Rome: Sapienza Universitá di Roma.

Mussen P., Eisenberg H. (1979). Helfen, Schenken, Anteilnehmen. Stuttgard: E. Klett - J.G. Cottasche.

Podmanický I. (2013). Teória a prax etickej výchovy 2. Vysokoškolské skriptá. Trnava: Pedagogická fakulta Trnavskej univerzity v Trnave.

Roche R.O. (1985). Antecedents educatius i familiars del comportament prosocial en nens de 13-14 años. "Quaderns de Psicologia", vol. 9-2, Bellaterra: UAB.

Roche R.O. (1992). Etická výchova. Bratislava: Orbis Pictus Istropolitana.

Roche R.O., Sol N. (1998). Educación prosocial de las Emociones, Valores y Actitudes positivas. Barcelona: Blume.

Warden D., Cheyne B., Christie D., Fitzpatrick H., Reid K. (2003). Assessing children's perceptions of prosocial and antisocial peer behaviour. "Educational Psychology", vol. 23 (5), pp. 547-567.

\section{PROSPOŁECZNE ROZUMOWANIE I ZACHOWANIE MORALNE. ROLA EDUKACJI ETYCZNEJ}

Streszczenie: W niniejszym tekście przeanalizowano związek zachodzący między oceną lekcji etyki przez uczniów a typem rozumowania moralnego, który oni prezentują. W celu zbadania tej zależności posłużono się trzema kwestionariuszami: kwestionariuszem prospołecznego rozumowania moralnego, kwestionariuszm zachowań prospołecznych w szkole i opracowanym przez autora niniejszej publikacji kwestionariuszem oceny lekcji etyki. Próba badawcza obejmowała uczniów klas szóstych z dwudziestu sześciu szkół podstawowych z zachodniej części Słowacji w liczbie 579 uczestników (49,7 \% dziewcząt, średnia wieku wyniosła 11,27, SD =0.71). Badanie dostarczyło dowodów na prawdziwość tezy, że pozytywne nastawienie do lekcji etyki wiąże się z wyższym poziomem rozumowania moralnego i powszechniejszym przejawianiem zachowań prospołecznych.

Słowa kluczowe: prospołeczne rozumowanie moralne, zachowanie prospołeczne, etyka, edukacja prospołeczna.

Martin Brestovanský - as a university teacher he focuses on theory and methodology of moral and character education, as well as experiential education methods. He leads, 
coordinates or cooperates on various projects in which both academic and praxis purposes are achieved: Erasmus+ strategic partnership RIDE - resources for inclusion, diversity and equality, national research project Theoretical investigation and empirical evaluation of prosociality concept as the base of actual Moral education conception in Slovak republic; the European Social Fund project Antiquity; international cooperation project N.E.W.S. and several others. He is a founder of Jama! (NGO) and Youth volunteer centre of the same name in Trnava. E-mail address: martin.brestovansky@truni.sk 